\title{
Floating Microspheres of Enalapril Maleate as a Developed Controlled Release Dosage Form: Investigation of the Effect of an Ionotropic Gelation Technique
}

\author{
Geliştirilmiş Kontrollü Salım Dozaj Formu Olarak Enalapril Maleat Yüzen \\ Mikroküreleri: İyonotropik Jelleşme Tekniğinin Etkisinin Araştırılması
}

\author{
(D) Ali Khidher ABBAS*, (D) Anas Tarik ALHAMDANY \\ Mustansiriyah University, College of Pharmacy, Department of Pharmaceutics, Baghdad, Iraq
}

\begin{abstract}
Objectives: The purpose of this study was to provide a control drug delivery system through a newly approved work to enhance the absorption and bioavailability of enalapril maleate loaded floating microspheres by ionotropic gelation technique using a hydrophilic carrier.

Materials and Methods: Eleven developed formulations of floating microspheres were prepared by ionotropic gelation using different concentrations of sodium alginate, iota-carrageenan, sodium bicarbonate, calcium chloride, and the drug. These microspheres were characterized using a diversity of parameters like micrometric properties, percentage yield, entrapment efficiency, in vitro buoyancy, in vitro drug release, and kinetics of drug release. The optimum formula was evaluated and identified for drug-excipients compatibility using fourier transform-infrared spectroscopy (FT-IR), surface morphology, powder X-ray diffraction (XRD), and differential scanning calorimetry (DSC).

Results: From the results, F4 was selected as the optimum formula since it provides a faster and premium release of drug from the matrix (91.4\%). Kinetics of drug release was found to depend on both diffusion and erosion mechanisms, as the correlation coefficient (R2) was best fitted with Korsmeyer's model and the release exponent $(n)$ was shown to be between 0.43 and 0.84 . Scanning electron microscopy images demonstrated spherical, discrete, and freely flowing microspheres with a particle size of $199.4 \pm 0.04 \mu \mathrm{m}$. Optimum buoyancy properties, percentage yield, and drug entrapment efficiency were achieved. FT-IR showed no interaction between enalapril and the polymers. DSC and XRD showed the miscibility of the drug with the polymers while maintaining the stable crystalline properties of enalapril loaded in the prepared microspheres.

Conclusion: The developed floating microspheres of enalapril maleate can be considered a promising controlled drug delivery system, thereby improving patient compliance.
\end{abstract}

Key words: Enalapril maleate, floating microspheres, gastroretentive system, iota-carrageenan, sodium alginate

Öz

Amaç: Bu çalışmanın amacı, bir hidrofilik taşıyıcı kullanılarak iyonotropik jelleștirme tekniği ile enalapril maleat yüklü yüzen mikro kürelerin emilimini ve biyoyararlanımını arttırmak için yeni onaylanmış bir çalışma ile kontrollü ilaç salım sistemi geliştirmektir.

Gereç ve Yöntemler: Bu çalışma kapsamında, yüzen mikrokürelerin onbir gelișmiş formülasyonu, sodyum aljinat, iota-carrageenan, sodyum bikarbonat, balmumu klorür ve ilacın farklı konsantrasyonları kullanılarak iyonotropik jelasyon yöntemi ile hazırlanmıştır. Bu mikrokürelerin karakterizasyonu, mikrometrik özellikler, yüzde verim, yükleme etkinliği, in vitro yüzme özelliği, in vitro ilaç salımı ve ilaç salım kinetiği gibi çeşitli parametreler kullanılarak yapıldı. Optimum formül, Fourier dönüșümü kızılötesi spektroskopisi (FT-IR), yüzey morfolojisi, toz X-ışını difraksiyonu (XRD) ve diferansiyel taramalı kalorimetri (DSC) kullanılarak ilaç-yardımcı madde uyumluluğu açısından değerlendirildi ve tanımlandı.

Bulgular: Elde edilen sonuçlardan, F4 matristen ilacın daha hızı salımını sağladığı için optimum formül olarak seçildi (\%91,4). Korelasyon katsayısının en iyi Korsmeyer'nin modeline uyması ve salım üs sayısının (n) 0,43-0,84 arasında olması nedeniyle ilaç salım kinetiğinin hem difüzyon hem de

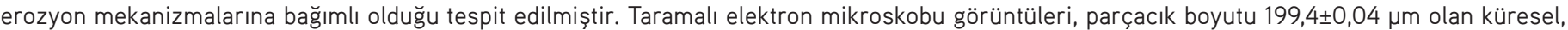
keskin ve serbestçe dönen mikroküreleri göstermektedir. Uygun yüzme özellikleri, yüzde verim ve ilaç yükleme etkinliği elde edilmiştir. FT-IR

*Correspondence: E-mail :alikidher@gmail.com, Phone: +9647702543633 ORCID-ID: orcid.org/0000-0001-5647-1221

Received: 08.11.2018, Accepted: 20.12.2018

Turk J Pharm Sci, Published by Galenos Publishing House. 
analizi, enalapril ve polimerler arasında hiçbir etkileşim olmadığını gösterdi. DSC ve XRD, hazırlanan enalapril yüklü mikrokürelerin stabil kristalin özelliklerini korurken, polimerler ile ilacın karıșabilirliğini de ortaya koymuștur.

Sonuç: Enalapril maleat yüklü geliștirilmiş yüzen mikrokürelerinin hasta uyuncunu iyileştirebilir nitelikte ümit vadeden kontrollü ilaç salım sistemi olarak kabul edilebileceği sonucuna varılabilir.

Anahtar kelimeler: Enalapril maleat, yüzen mikroküre, gastroretentif yüzen ilaç taşıyıcı sistem, iota-carrageenan, sodyum aljinat

\section{INTRODUCTION}

Conventional drug delivery systems have insufficient control over drug release and concentration at the target site because of amendments in the concentration of the bioactive product. Moreover, drug absorption in traditional dosing is dependent on the body's capability to assimilate the therapeutic molecule. ${ }^{2}$ Thus, the development of modern administration techniques to maintain steady-state plasma concentration can be achieved through controlled drug release that supports unceasing drug delivery for a programmed period with foreseeable, reproducible kinetics and a drug release mechanism. ${ }^{3}$ Once achieved, the effectiveness of the drug and patient compliance are enhanced by reducing the frequency of administration. ${ }^{4}$

Microspheres have played a key role in the progress of controlled release systems, as they can encapsulate miscellaneous types of drugs and small molecules, nucleic acids, and proteins. ${ }^{5}$ They are biocompatible, can deliver superior bioavailability, and are able to release over longer periods. ${ }^{6}$ In addition, microspheres have been technologically advanced by numerous techniques comprising combinations of phase separations or precipitations, emulsion or solvent evaporation, and spraying methods. ${ }^{7}$

Floating microspheres are one of the most promising buoyant gastroretentive drug delivery systems. These are free-flowing spherical empty particles without a core, with size varying from 1 to $1000 \mu{ }^{8}{ }^{8}$ The gastrointestinal transit-controlled preparations are intended to float on gastric juice with a specific density of less than one, and due to this property a delayed transit through the stomach occurs. ${ }^{9}$ The slowly released drug at a preferred rate results in enhanced gastric retention with abridged fluctuations in plasma drug concentration. ${ }^{10}$

lonotropic gelation is used mainly in our study; however, natural hydrophilic polymers (polyelectrolytes) are used to prepare drug carriers due to their ability to cross-link in the existence of counter ions to form microspheres."1 These polymers, including sodium alginate, gellan gum, and hydroxypropyl methylcellulose, are used extensively for the encapsulation of drugs and act as a release rate retardant. ${ }^{12}$ For instance, this technique has the virtue of not using organic solvents. ${ }^{13}$

Sodium alginate is, in fact, a water-soluble polymer that becomes a gel in the incidence of polyvalent cations such as calcium chloride, though it is built on the transition of the polymer from a liquid state to a gel. ${ }^{14}$ These gels are constituted by dropping a drug-loaded polymeric solution into an aqueous solution of multivalent cations. The cations diffuse into the drug-loaded polymeric drops, creating a three-dimensional lattice of the ionically cross-linked moiety. ${ }^{15}$

Enalapril maleate is a pro-drug employed in the treatment of hypertension. After oral administration, it becomes hydrolyzed in the liver to release the enalaprilat, which acts as an ACE inhibitor. The extent of absorption of enalapril maleate after oral administration is approximately $60 \%$ and due to the high hepatic first-pass metabolism of the prodrug (enalapril maleate) to the active form of the drug (enalaprilat) in the gastrointestinal tract before absorption the bioavailability of enalaprilat becomes approximately $40 \%{ }^{16}$

The objective of the present study was to overcome the reduction in bioavailability as a result of the lack of absorption. An attempt is needed to provide a control drug delivery system through this newly approved work for enhancing the absorption and bioavailability of enalapril maleate loaded floating microspheres by ionotropic gelation technique using a hydrophilic carrier.

\section{MATERIALS AND METHODS}

\section{Materials}

Enalapril maleate (Baoji Guokang Bio-Technology, China), sodium alginate (Avonchem, UK), iota-carrageenan (Provizer Pharma, India), and calcium chloride (Gainland Chemical Company, UK) were obtained. All other materials used were of pharmaceutical grade.

\section{Methods}

\section{Preparation of floating microspheres}

Floating microspheres were prepared through ionotropic gelation by dissolving the primary polymer (sodium alginate) in distilled water at different concentrations and heating to $60^{\circ} \mathrm{C}$ while stirring. To this dispersion was added dissolved iota-carrageenan in different concentrations while stirring and the heating was continued. The required amount of sodium bicarbonate was added to the above solution in a suitable proportion and mixing continued. To this successive solution was added the drug after cooling. The drug and polymer solution was added dropwise through a syringe with a 31-gauge needle into $100 \mathrm{~mL}$ of calcium chloride solution and stirred at 200 rpm. The microspheres formed were kept suspended in the solution for $1 \mathrm{~h}$ to improve their mechanical strength and then collected by filtration. After that, the floated microspheres were washed with $100 \mathrm{~mL}$ of distilled water 3 times and then dried in a hot air oven for $2 \mathrm{~h}$ at $50^{\circ} \mathrm{C}$ to be stored in a desiccator..$^{17}$ The composition of the floating microspheres is given in Table 1.

\section{Characterization of floating microspheres}

\section{Micrometric properties}

The floating microspheres were characterized by numerous tests to detect their properties that obey USP standards. 


\section{Particle size analysis}

The floating microspheres were separated into different size fractions by sieving for 10 min through a series of standard sieves, \#40, \#60, \#80, and \#100, and the particle size of 50 floating microspheres was calculated using an optical microscope (Novel, China) and the mean particle size was calculated. ${ }^{18}$

\section{Bulk density}

A weighed quantity of floating microspheres was poured into a graduated cylinder $(10 \mathrm{~mL})$. Bulk density was established by a ratio of the mass of floating microspheres to bulk volume. ${ }^{19}$

Bulk density=Mass/Bulk volume

\section{Tapped density}

A weighed quantity of floating microspheres was introduced into a graduated cylinder $(10 \mathrm{~mL})$ and the cylinder was tapped from a height of $2 \mathrm{~cm}$ for 100 standard taps until there was no more diminution in the density and the volume of the microspheres was calculated. ${ }^{20}$

Tapped density=Mass/Tapped volume

\section{Carr's (compressibility) index}

The compressibility index of microparticles has been anticipated to be a subsidiary measure of the bulk density, size, and shape, surface area, moisture content, and cohesiveness of materials. ${ }^{21}$

$\%$ Compressibility index=Tapped density-Bulk density $\times 100 /$ Tapped density

\section{Hausner ratio}

The Hausner ratio of the floating microspheres was confirmed by associating the tapped density with the bulk density as shown in the following equation. ${ }^{22}$

Hausner ratio=Tapped density/Bulk density

Table 1. Formulation of enalapril maleate floating microspheres

\begin{tabular}{llllll}
\hline Formulations & $\begin{array}{l}\text { Drug } \\
(\mathrm{mg})\end{array}$ & $\begin{array}{l}\text { Sodium } \\
\text { alginate } \\
(\mathrm{mg})\end{array}$ & $\begin{array}{l}\text { lota-carrageenan } \\
(\mathrm{mg})\end{array}$ & $\begin{array}{l}\text { Sodium } \\
\text { bicarbonate }\end{array}$ & $\begin{array}{l}\mathrm{CaCl}_{2} \\
(\%)\end{array}$ \\
\hline $\mathbf{1}$ & 20 & 500 & 100 & 200 & 2 \\
\hline $\mathbf{2}$ & 20 & 1000 & 100 & 200 & 2 \\
\hline 3 & 20 & 1500 & 100 & 200 & 2 \\
\hline 4 & 20 & 1000 & 200 & 200 & 2 \\
\hline 5 & 20 & 1000 & 400 & 200 & 2 \\
\hline 6 & 20 & 1000 & 200 & 400 & 2 \\
\hline 7 & 20 & 1000 & 200 & 800 & 2 \\
\hline 8 & 10 & 1000 & 200 & 200 & 2 \\
\hline 9 & 5 & 1000 & 200 & 200 & 2 \\
\hline 10 & 20 & 1000 & 200 & 200 & 4 \\
\hline 11 & 20 & 1000 & 200 & 200 & 1 \\
\hline
\end{tabular}

$\mathrm{CaCl}_{2}$ : Calcium chloride

\section{Angle of repose}

The flow of floating microspheres was measured by assessing the angle of repose using the funnel method. Prepared microspheres were poured via a funnel fixed $1 \mathrm{~cm}$ above a flat surface until the apex of the microsphere pile touched the tip of the funnel. ${ }^{23}$ The angle of repose is calculated by the following equation:

$\theta=\operatorname{Tan}^{-1}(h / r)$,

where $\theta=$ angle of repose, $h=$ height of pile, and $r=$ radius of the pile.

\section{Determination of percentage yield}

The calculation of floating microsphere percentage yield was premeditated using the weight of a dried final product regarding the total weight of the drug and polymer measured initially and used for the preparation of microspheres. ${ }^{24}$ The percentage yields were calculated as per the formula

Percentage yield=[Weight of microspheres obtained/(Weight of drug+polymer)] $\times 100$

\section{Determination of entrapment efficiency}

Floating microspheres can be assessed for their drug content and it can be approved by dissolving weighed amounts of crushed microspheres (through a hammer mill) in $100 \mathrm{~mL}$ of $0.1 \mathrm{~N} \mathrm{HCl}$. An aliquot of $1 \mathrm{~mL}$ was taken and diluted to 10 $\mathrm{mL}$; after that the mixture was shaken and filtered through a $0.45 \mu \mathrm{m}$ filter and then analyzed using a ultraviolet (UV) spectrophotometer (Shimadzu 8400S, Japan) at $219 \mathrm{~nm}$ using the calibration curve. ${ }^{25}$ Each batch should be examined for drug content in triplicate.

$\%$ Entrapment efficiency=(Actual drug content)/(Theoretical drug content) $\times 100$

\section{Determination of in vitro buoyancy}

In vitro buoyancy was determined to study the floatation behavior of microspheres in the prepared formulations. First 50 $\mathrm{mg}$ of microspheres was spread in $0.1 \mathrm{~N} \mathrm{HCl}(\mathrm{pH} \mathrm{1.2;} 100 \mathrm{~mL})$. The mixture was then stirred at $100 \mathrm{rpm}$ in a magnetic stirrer. After 8 h, the buoyant microparticles layer was collected by pipette and separated by filtration. The particulate sinking layer particles were separated by filtration. Particles of both types were dried in a desiccator until a constant weight was obtained. ${ }^{26}$ The buoyancy percentage was calculated by the following equation:

$\%$ Buoyancy=(Weight of floating microspheres)/(Total weight of floating and settled microspheres) $\times 100$

All the determinations were conducted in triplicate.

\section{In vitro drug release study}

The in vitro drug release rate from the floating microspheres was affirmed using a paddle type six-station dissolution test apparatus (Copley, UK). An accurate amount of floating microspheres equivalent to 5,10 , and $20 \mathrm{mg}$ of drug was kept in $0.1 \mathrm{~N} \mathrm{HCl}(1.2 \mathrm{pH})$ and the dissolution fluid was maintained at $37 \pm 0.5^{\circ} \mathrm{C}$ at a speed of rotation of $50 \mathrm{rpm}$. Sink conditions prevailed during the in vitro drug release study. A 4- $\mu \mathrm{L}$ sample 
was withdrawn and filtered through a $0.45-\mu \mathrm{m}$ membrane filter at $5,10,15,20,30,60,120,180,240,300,360,480$, 600,720 , and $1440 \mathrm{~min}$. The initial volume of the dissolution fluid was maintained by adding $4 \mathrm{~mL}$ of fresh dissolution fluid after each withdrawal. The samples were analyzed by UV spectrophotometer at $219 \mathrm{~nm}$ to determine the concentration of enalapril maleate present in the medium. ${ }^{27}$ All experiments were performed in triplicate.

\section{Kinetics of drug release}

To determine the mechanism and kinetics of drug release, the results of the in vitro dissolution study of enalapril microspheres were obtained for various kinetic equations. The kinetics models used were zero order, first order, Higuchi's, and KorsmeyerPeppas. Correlation coefficient $\left(R^{2}\right)$ values were calculated for the linear curves obtained by regression analysis. ${ }^{16}$

\section{Drug-excipients compatibility study and identification}

Fourier transfor-infrared spectroscopy (FT-IR)

The FT-IR spectra of pure drug, polymers (sodium alginate and iota-carrageenan), and the drug with the polymer (F4 as microspheres) were recorded on a spectrophotometer (Shimadzu 8400S, Japan) using the $\mathrm{KBr}$ pellet technique and reported as wave number $\left(\mathrm{cm}^{-1}\right)$. The scanning range was from 4000 to $450 \mathrm{~cm}^{-1}$. The FT-IR spectra support the identification of the functional groups present in the compound. The FTIR spectra are also used in comparing with a standard FT$\mathrm{IR}$ spectrum of the pure drug to detect any physicochemical incompatibility between the drug and different excipients. ${ }^{28}$

\section{Surface morphology}

Scanning electron microscopy (SEM) was used to characterize the surface and cross-sectional morphology of the designed floating microspheres. SEM samples were mounted directly by scattering the powder lightly on dual adhesive tape fixed to an aluminum stub. Then gold/palladium coating of stubs was conducted to about $20 \mathrm{~nm}$ thickness under an argon atmosphere by a gold sputter module in a high vacuum evaporator. The coated samples were then scanned haphazardly, and photographs were taken with SEM (TESCAN, VEGA 3-Czech Republic). ${ }^{29}$

\section{Powder X-ray diffraction (PXRD)}

The PXRD patterns of enalapril alone, sodium alginate, iotacarrageenan, and F4 were recorded using XRD (Shimadzu 6000 , Japan) with a CuK $\alpha$ line as the source of radiation. Standard runs were executed with a current of $30 \mathrm{~mA}$, a voltage of $40 \mathrm{KV}$, and a scanning rate of $8 \mathrm{deg} / \mathrm{min}$ over a $\theta$ range of $5-80^{\circ}$ using a step size of $0.02^{\circ}$ per second. It was therefore used to determine the nature of the pure drug, whether it was crystalline or amorphous, and to examine the nature of the drug as to whether it was changed or not by using a combination of polymers. ${ }^{30}$

\section{Differential scanning calorimetry (DSC)}

Thermal analysis was achieved by differential scanning calorimeter (STA PT-1000, LINSEIS-Germany) equipped with argon as an inert gas to study the drug and the microspheres' crystalline changeability. The accurate weights of enalapril alone, sodium alginate, iota-carrageenan, and F4 were recorded. Weighed samples were put into aluminum pans and hermetically sealed. The samples were heated from $20^{\circ} \mathrm{C}$ to $200^{\circ} \mathrm{C}$ at a rate of $5^{\circ} \mathrm{C}$ per minute under an argon atmosphere with a gas flow rate of $100 \mathrm{~mL} / \mathrm{min}$. A covered, empty pan was used as a reference. The results obtained from the heating were recorded. ${ }^{31}$

\section{Statistical analysis}

The results were stated as an average value $\pm S D$ and were analyzed using single factor analysis of variance (ANOVA) to compare the sample means and to determine the statistical significance, at which $\mathrm{p}<0.05$ was considered significant.

The study did not require ethics committee approval or patient informed consent.

\section{RESULTS AND DISCUSSION}

\section{Characterization of floating microspheres}

\section{Micrometric properties}

The floating microsphere formulations were evaluated to detect their micrometric properties as detailed below.

\section{Particle size analysis}

The mean particle size of the floating microsphere formulations (F1-F11) was in the range of $196.55 \pm 0.28$ to $520.2 \pm 0.09 \mu \mathrm{m}$ as shown in Table 2. Formulations representing an increase in sodium alginate concentration (F1-F3) showed an increase in particle size. This could be ascribed to an increase in relative viscosity at higher concentration of sodium alginate, which requires high energy for breaking of droplets, and is more difficult to disperse due to enhancement of interfacial tension and diminished shearing efficiency, leading to the formation of large droplets of floating microspheres during the addition of polymer solution to the gelling agent. ${ }^{32}$

In addition, the particle diameter in formulations F4 and F5 increased gradually as the concentration of iota-carrageenan increased. This may be attributed to the increase in gel strength and the formation of strong bridges between anionic iotacarrageenan molecules and cationic $\mathrm{CaCl}_{2}$ salts, leading to helix-helix aggregation of the adjacent spiral chains that contain sulfate groups and the formation of a stable three-dimensional network. ${ }^{33}$

Furthermore, formulations F2 and F6 showed that the particle size of floating microspheres increased as the sodium bicarbonate content increased. On the other hand, a further increase in sodium bicarbonate concentration caused a decrease in the particle size of microspheres as shown in F7. The suggested mechanism demonstrates that as the concentration of sodium bicarbonate increases the microspheres expand and increase in size. An additional increase in sodium bicarbonate concentration will make them burst and decrease in size. ${ }^{34}$ 
The effect of drug concentration on microsphere size was studied using F8 and F9, which showed an increase in the particle size of microspheres as the drug concentration decreased. This factor was related to the solubility of microspheres, which decreased with decreasing drug concentration, thus making these microspheres more rigid and larger in terms of particle size. ${ }^{35}$

The effect of the crosslinking agent $\left(\mathrm{CaCl}_{2}\right)$ on particle size was detected in $\mathrm{F} 10$ and $\mathrm{F} 11$; as the concentration of calcium chloride increased, the mean particle size of microspheres increased. This is related to the availability of a high amount of $\mathrm{Ca}^{2+}$, which crosslinked with sodium alginate and iotacarrageenan polymers, thereby leading to the formation of larger microspheres. ${ }^{36}$

\section{Rheological parameters of floating microspheres}

Rheological studies of enalapril maleate floating microspheres involved bulk density, tapped density, compressibility index or Carr's index, the Hausner ratio, and angle of repose. The formulations were studied for all rheological properties as shown in Table 2.

\section{Bulk and tapped density}

The bulk density and tapped density of formulations F1, F2, and F3 may be triggered by a small difference in flow properties as shown in Table 2. This is due to the use of low polymer dispersion concentrations in $\mathrm{F} 1$; thus the microspheres did not have as good a spherical shape as F2 and had a flattened base at the points of contact with the drying vessels; however, an increase in the concentration of sodium alginate dispersion in F2 tended to make the particles more spherical. This indicates that at low alginate concentrations the particles were composed of a loose network structure that collapsed during drying. On the other hand, a higher sodium alginate concentration formed a dense matrix structure, which prevented the collapse of microspheres. As the concentration of sodium alginate in the aqueous dispersion increased in $\mathrm{F} 3$ the relative viscosity of dispersion increased and it was difficult to transfer polymer dispersion through the needle into the cross-linking agent solution and an increase in concentration moreover caused a small tail at one end of the microspheres, which significantly affected the flow properties and particle size distribution. ${ }^{37}$

Floating microspheres prepared with an increased concentration of iota-carrageenan (F4 and F5) showed a decrease in bulk and tap density. The reason behind this was the swelling property of the material, which absorbs fluid from the surrounding environment in a controlled manner, making it float above the gastric contents and remain unaffected by the gastric emptying time. ${ }^{38}$

Upon an increment in sodium bicarbonate concentration in F4, F6, and F7, the microspheres became more floated as the density dropped below $1.0 \mathrm{~g} / \mathrm{cm}^{3}$. This indicated that when the spheres come in contact with the medium $(0.1 \mathrm{~N} \mathrm{HCl}, \mathrm{pH} 1.2)$, they start to react and generate $\mathrm{CO}_{2}$ gas with upward force and become entrapped within the matrix of sodium alginate and iota-carrageenan. This entrapment of $\mathrm{CO}_{2}$ leads to a decrease in microsphere density; thereby they become buoyant. ${ }^{39}$

Formulations of floating microspheres representing a decrease in enalapril maleate content (F8 and F9) showed a high level of bulk and tapped density. This is related to the high porosity in the spheres' matrix, which increases medium flowability directly into these floating microspheres, making them denser. ${ }^{40}$ It was evident that bulk and tapped density increased in F4, F10, and $\mathrm{F} 11$ as the concentration of $\mathrm{CaCl}_{2}$ increased. This is due to the higher concentration of crosslinking agent, which will lead to an increment in viscosity, thereby increasing the density of microspheres. ${ }^{41}$

\section{Compressibility index or Carr's index}

Carr's index is an indicator of the tendency to form bridges between microspheres. Thus, the values for all formulations were in the range of $2.36 \pm 0.1 \%$ and $12.79 \pm 0.29 \%$ as shown in Table 2, which displayed an excellent flow of microspheres and excellent compressibility. ${ }^{42}$

\section{Hausner ratio}

The Hausner ratio was measured to indicate the cohesion between microsphere particles. The values of all formulations

Table 2. Micrometric properties of enalapril maleate floating microspheres

\begin{tabular}{lllllll} 
Formula code & Particle size $(\mu \mathrm{m})$ & Bulk density $(\mathrm{g} / \mathrm{cc})$ & Tapped density $(\mathrm{g} / \mathrm{cc})$ & Compressibility index $(\%)$ & Hausner ratio & Angle of repose \\
\hline F1 & $196.55 \pm 0.28$ & $0.463 \pm 0.12$ & $0.493 \pm 0.09$ & $6.08 \pm 0.05$ & $1.06 \pm 0.03$ & $13.52 \pm 0.34$ \\
\hline F2 & $242.10 \pm 0.17$ & $0.497 \pm 0.04$ & $0.537 \pm 0.11$ & $7.44 \pm 0.03$ & $1.08 \pm 0.07$ & $15.90 \pm 0.22$ \\
\hline F3 & $520.2 \pm 0.09$ & $0.908 \pm 0.23$ & $0.99 \pm 0.17$ & $8.28 \pm 0.02$ & $1.09 \pm 0.09$ & $18.4 \pm 0.16$ \\
\hline F4 & $199.4 \pm 0.04$ & $0.812 \pm 0.02$ & $0.860 \pm 0.07$ & $5.58 \pm 0.01$ & $1.06 \pm 0.05$ & $17.64 \pm 0.11$ \\
\hline F5 & $429.3 \pm 0.09$ & $0.785 \pm 0.14$ & $0.837 \pm 0.12$ & $6.21 \pm 0.09$ & $1.07 \pm 0.11$ & $18.9 \pm 0.24$ \\
\hline F6 & $403.2 \pm 0.13$ & $0.777 \pm 0.08$ & $0.891 \pm 0.32$ & $12.79 \pm 0.29$ & $1.14 \pm 0.15$ & $16.74 \pm 0.09$ \\
\hline F7 & $372.6 \pm 0.18$ & $0.763 \pm 0.16$ & $0.871 \pm 0.26$ & $12.39 \pm 0.33$ & $1.03 \pm 0.08$ & $13.21 \pm 0.31$ \\
\hline F8 & $347.4 \pm 0.21$ & $0.812 \pm 0.25$ & $0.840 \pm 0.27$ & $3.33 \pm 0.17$ & $1.02 \pm 0.04$ & $18.1 \pm 0.17$ \\
\hline F9 & $421.2 \pm 0.06$ & $0.799 \pm 0.22$ & $0.820 \pm 0.21$ & $2.56 \pm 0.11$ & 1.06 & $19.32 \pm 0.13$ \\
\hline F10 & $458.4 \pm 0.14$ & $0.880 \pm 0.31$ & $0.900 \pm 0.05$ & $6.38 \pm 0.08$ & $2.36 \pm 0.1$ & $1.02 \pm 0.06$ \\
\hline F11 & $298.8 \pm 0.15$ & $0.704 \pm 0.09$ & $0.721 \pm 0.03$ & $16.5 \pm 0.17$ & $20.22 \pm 0.25$ \\
\hline
\end{tabular}


were below 1.25, as shown in Table 2, thus indicating good flow properties with easy handling during processing. ${ }^{43}$

\section{Angle of repose}

Values of the angle of repose of all formulations were below $21^{\circ}$, as shown in Table 2 , indicating free-flow properties of microspheres. The better flow of microspheres indicates that the floating microspheres produced were nonaggregated. Similar findings were reported for novel floating microspheres of metronidazole. ${ }^{44}$

\section{Percentage yield}

The percentage yield of floating microsphere was examined to determine the polymer effect (sodium alginate) on the formulations. The results showed that the percentage yields of formulas $F 1$ to $F 3$ range from $54.5 \pm 0.925$ to $72.88 \pm 0.672$, as shown in Table 3. It is obvious that the increment in polymer concentration led to an increase in percentage yield. This effect can be explained by the fact that as the concentration of alginate increases the quantity of polymer becomes adequate to cover enalapril maleate particles completely. In addition, the microspheres become well distributed, discrete, and spherical and have no clumping, thus giving a good percentage of yield. ${ }^{45}$

The increment in iota-carrageenan concentration will instantaneously lead to interfacial cross-linking taking place, followed by a more gradual gelation of the interior, which results in an increase in the percentage yield as shown in F4. From the results, it was noted that the viscosity increased dramatically with the further increase in iota-carrageenan concentration, which may retard the penetration of the enalapril into the matrix and hence decrease percentage yield, as shown in F5. ${ }^{46}$

Formulations prepared with an increased concentration of sodium bicarbonate as a gas forming agent (F6 and F7) were observed to have a decrease in the percentage of yield. The microspheres with a small amount of sodium bicarbonate will have a highly dense internal structure of the matrix and they will be able to retain enalapril more effectively as shown in

Table 3. Percentage yield, drug entrapment efficiency, and in vitro buoyancy

\begin{tabular}{llll} 
Formula code & Percentage yield & Entrapment efficiency & Buoyancy (\%) \\
\hline F1 & $54.5 \pm 0.92$ & $73.4 \pm 0.07$ & $80.22 \pm 0.21$ \\
\hline F2 & $67.07 \pm 0.87$ & $81.5 \pm 0.05$ & $76.12 \pm 0.53$ \\
\hline F3 & $72.88 \pm 0.67$ & $84.3 \pm 0.15$ & $68.89 \pm 0.44$ \\
\hline F4 & $91.18 \pm 0.24$ & $92.3 \pm 0.04$ & $92.41 \pm 0.21$ \\
\hline F5 & $84.2 \pm 0.36$ & $88.7 \pm 0.09$ & $70.17 \pm 0.37$ \\
\hline F6 & $69.3 \pm 0.46$ & $76.15 \pm 0.11$ & $72.21 \pm 0.77$ \\
\hline F7 & $68.8 \pm 0.21$ & $72.15 \pm 0.08$ & $71.43 \pm 0.55$ \\
\hline F8 & $75.9 \pm 0.23$ & $78.2 \pm 0.06$ & $82.95 \pm 0.41$ \\
\hline F9 & $82.7 \pm 0.35$ & $72.8 \pm 0.12$ & $74.10 \pm 0.34$ \\
\hline F10 & $72.38 \pm 0.23$ & $80.5 \pm 0.17$ & $50.92 \pm 0.74$ \\
\hline F11 & $85.4 \pm 0.27$ & $83.5 \pm 0.03$ & $78.54 \pm 0.82$ \\
\hline
\end{tabular}

F4. The porous microspheres with an increment in the amount of sodium bicarbonate, having a less dense internal structure, resulted in a decrease in the percentage of yield of the drug. ${ }^{47}$

The high enalapril percentage of yield in F4 might have been due to the higher water solubility of a freely soluble drug, which is always entrapped in a higher ratio, making diffusion out of the microspheres from the gel surface difficult during the hardening of the carrageenan gel matrix. This percentage of yield decreased when the drug content decreased, as seen in F8 and F9. ${ }^{48}$

The effect of increasing $\mathrm{CaCl}_{2}$ concentration in $\mathrm{F} 10$ appears in the degree of cross-linking, which will be increased, and so the percentage yield decreased due to the difficulty of drug penetration into the microspheres. Moreover, the percentage of yield in $\mathrm{F} 11$ increased with decreasing $\mathrm{CaCl}_{2}$ concentration. The reason for the high percentage yield may have been the high solubility of the drug, which will be more entrapped within the matrix of microspheres. ${ }^{49}$

\section{Entrapment efficiency}

Drug entrapment was related to the permeation characteristics of polymers used, which could simplify the diffusion of a part of the drug that was entrapped in the medium during the preparation of floating microspheres. Drug entrapment efficiency increased with the increment in polymer concentration (F1-F3) as shown in Table 3. This is due to the increase in polymer content and so more particles of enalapril would be coated, leading to higher encapsulation efficiency. ${ }^{11}$

The entrapment efficiency of iota-carrageenan in F4 and F5 decreased with an increment in polymer concentration in the gastric medium. This is because of the increment in the viscosity with the further increase in iota-carrageenan concentration, which may retard the penetration of the enalapril into the microspheres and hence decrease entrapment efficiency. ${ }^{50}$

Table 3 showed that as the amount of sodium bicarbonate (as gas forming agent) increased (F4, F6, and F7), a decrease in entrapment efficiency was observed. Microspheres with low gas forming agents showed high entrapment efficiency as compared to those with high gas-forming agents. This result was attributed to the fact that microspheres with a low gas forming agent have an excessively compact internal structure able to keep the drug within its matrix, as compared to the less dense internal structure of the other microspheres, which consisted of a high amount of gas forming agents that cause a decrease in drug entrapment. As a result, the formation of more pores on the microspheres networks with an increased amount of sodium bicarbonate will make them have lower drug entrapment efficiency. ${ }^{51}$

Microspheres for formulations of F8 and F9 were designed with different drug concentrations. The decrease in entrapment efficiency was achieved by decreasing drug concentration. This results from a lower concentration gradient in which the drug may diffuse out of the microsphere matrix to the external medium during preparation, which tends to decrease encapsulation efficiency. ${ }^{52}$ 
The effect of $\mathrm{CaCl}_{2}$ on encapsulation efficiency was observed in formulations F10 and F11. The percentage encapsulation efficiency decreases with the increase in the concentration of calcium chloride as shown in F10. For microspheres crosslinked with a low level of $\mathrm{CaCl}_{2}$ (F11) a higher drug encapsulation efficiency was seen in comparison to high levels of calcium chloride. This may be as a result of the immediate gelling of polymer (sodium alginate) on the addition of $\mathrm{CaCl}_{2}$ and thrust out of the aqueous phase from the gel lattice. ${ }^{53}$

\section{In vitro buoyancy}

The buoyancy percentage was calculated for all the formulations and it was found that all formulations were able to float on the dissolution medium $(0.1 \mathrm{~N} \mathrm{HCl}, \mathrm{pH} 1.2)$ for $24 \mathrm{~h}$. The buoyancy percentage of the microspheres was found to decrease with an increase in sodium alginate concentration represented by F1-F3, as shown in Table 3. This is because of the elevated viscosity of the polymer solution, which in turn is the reason for more dense microspheres and less formation of pores in addition to cavities during preparation. ${ }^{54}$

Moreover, the increasing iota-carrageenan concentration in $\mathrm{F} 2$ and $\mathrm{F} 4$ resulted in an increment in microsphere buoyancy. This was due to the immediate crosslinking of the microsphere matrix as an outcome of the strongly acidic sulfate groups in the iota-carrageenan molecule, which allow a certain degree of polymer ionization in $0.1 \mathrm{~N} \mathrm{HCl}(\mathrm{pH} \mathrm{1.2)}$, leading to the formation of an insoluble gel-like layer of aggregated doublehelical segments that form a three-dimensional network by complexation, and consequently slower solvent penetration into the matrices, and more controlled $\mathrm{CO}_{2}$ diffusion was achieved, thus inducing the microspheres to float rapidly. ${ }^{5} \mathrm{~A}$ further increment in iota-carrageenan concentration, as shown in F5, will lead to a decrease in the buoyancy effect. This was related to the increment in iota-carrageenan viscosity as the concentration rose. Thus, more entrapment of $\mathrm{CO}_{2}$ gas and less gastric medium penetration into the matrices will lead to a decrease in buoyancy of enalapril microspheres.

The effect of increasing $\mathrm{NaHCO}_{3}$ concentration on buoyancy was shown to be nonsignificant and is represented in F6 and F7. The reason behind this was the properties of sodium alginate, causing strong crosslinking in the polymer matrix, and addition of $\mathrm{NaHCO}_{3}$ decreased the elasticity of the matrix without affecting viscosity, and so the buoyancy was not affected. ${ }^{56}$

The effect of drug loading of microspheres was shown in F8 and F9. From the results, as the quantity of drug increased, more drug molecules were available at the surface of microspheres. In addition, more solid drug particles will begin to form continuous pores or channels within the matrix. Under these circumstances, the path of least resistance for drug molecules will be diffusion within the channels formed from areas where the drug has previously leached out from the matrix. Therefore, as the amount of drug content is increased and drug leaches out from the polymer, the matrix becomes more porous and higher buoyancy occurs. Lower drug contents create fewer pores within the polymeric network; hence a lower rate of drug diffusion was observed and lower buoyancy was achieved. ${ }^{57}$
Buoyancy was found to decrease with increasing $\mathrm{CaCl}_{2}$, as shown in $\mathrm{F} 10$ and $\mathrm{F} 11$. $\mathrm{CaCl}_{2}$ might be responsible for producing a more viscous matrix, which may block the pores on the surface of microspheres. Thus, a higher concentration of $\mathrm{CaCl}_{2}$ can produce a high degree of cross-linking and thereby decreasing buoyancy from enalapril microspheres. ${ }^{58}$

\section{In vitro drug release}

The effect of different concentrations of sodium alginate on drug release in F1-F3 was significant ( $p<0.05$ ), as shown in Figure 1. The release of enalapril from the prepared alginate microspheres was distinguished by an initial phase of high release (burst effect) followed by the second phase of moderate release. This biphasic manner of release is a distinctive feature of matrix diffusion kinetics. ${ }^{59}$ A significant decrease in drug release was noted with an increment in the drug/polymer ratio in the prepared microspheres and is related to an increment in the density of the polymer matrix and in the diffusional path length that the drug molecules must traverse. ${ }^{60}$

The release profile in Figure 2 represents a significant effect $(p<0.05)$ between formulations F2, F4, and F5. These formulations determine the influence of different concentrations of iota-carrageenan on the drug released. Two distinctive release steps were detected, where the initial rapid release was due to diffusion, while the second step was due to erosion of the matrix. A faster release in F4 in comparison to F2 was observed because of the presence of high-water content molecules in the matrix. The existence of a higher concentration of iota-carrageenan leads to higher release of the drug. It was suggested that the pore size in F4 was higher than in F2, resulting in higher release. ${ }^{61} A$ further increase in iota-carrageenan concentration, as shown in F5, caused

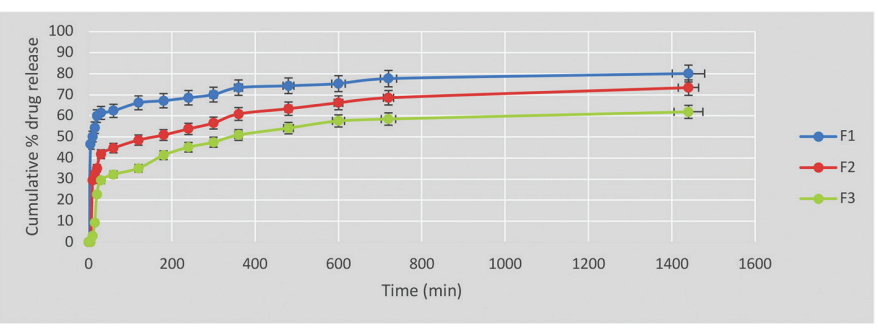

Figure 1. Dissolution profile of enalapril from floating microspheres containing different concentrations of sodium alginate (F1-F3), data given in mean $\pm \mathrm{SD}, \mathrm{n}=3$

SD: Standard deviation

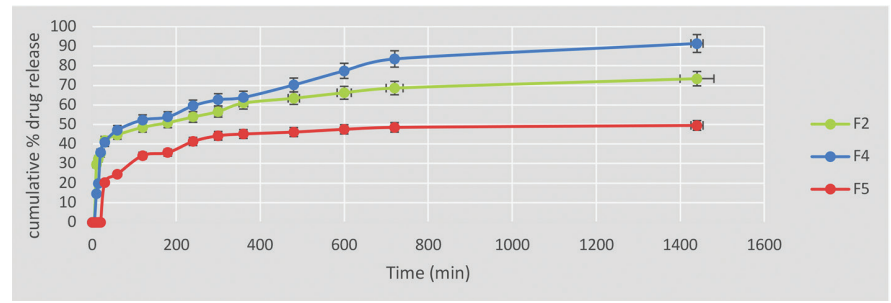

Figure 2. Dissolution profile of enalapril from floating microspheres containing different concentrations of iota-carrageenan (F2, F4, and F5), data given in mean $\pm S D, n=3$

SD: Standard deviation 
a decrease in drug release. This was ascribed to the gelling property of the polymer, which could sustain the drug release from its matrix as well as the ability to wet. The gel matrix will swell and withstand erosion under acidic conditions to maintain a constant diffusion path length, forming a highly crosslinked matrix with minimum porosity. ${ }^{55}$

Moreover, it was noted from the in vitro release study that the drug release rate increased nonsignificantly ( $p>0.05)$ with an increase in the proportion of $\mathrm{NaHCO}_{3}(\mathrm{~F} 4, \mathrm{~F} 6$, and F7), as shown in Figure 3. This was ascribed to the low concentration of $\mathrm{NaHCO}_{3}$; the alginate produces a highly dense internal structure and so a minimal amount of drug is released, but in the presence of higher concentrations of $\mathrm{NaHCO}_{3}$ the formulations become more porous and the drug is released in a faster manner.

The effect of enalapril concentration on drug release profile in F4, F8, and F9 represents a nonsignificant effect ( $p>0.05$ ), as shown in Figure 4. It was noted that at a higher drug concentration in $\mathrm{F} 4$ less than $92 \%$ of the drug was released in $24 \mathrm{~h}$ as compared to $100 \%$ drug release from microspheres with lower drug concentrations in F8 and F9. In contrast to the low enalapril-loaded microspheres that exhibited smooth surfaces, the highly loaded enalapril microspheres showed rippled and rough surfaces. No enalapril crystals were observed embedded or attached firmly to the surface of the low enalapril loaded microspheres. Thus, this surface structure should be attributed to possible molecular interactions between the coating polymer and the enalapril rather than to an excess of incorporated drug, which might result in recrystallization of enalapril within the microspheres as was the case with the high enalapril loaded microspheres. ${ }^{62}$

The results of the in vitro drug release study indicated that

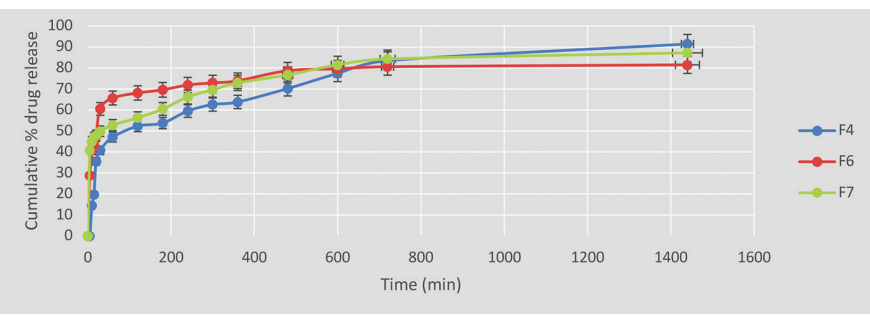

Figure 3. Dissolution profile of enalapril from floating microspheres containing different concentrations of sodium bicarbonate (F4, F6, and F7), data given in mean $\pm S D, n=3$

SD: Standard deviation

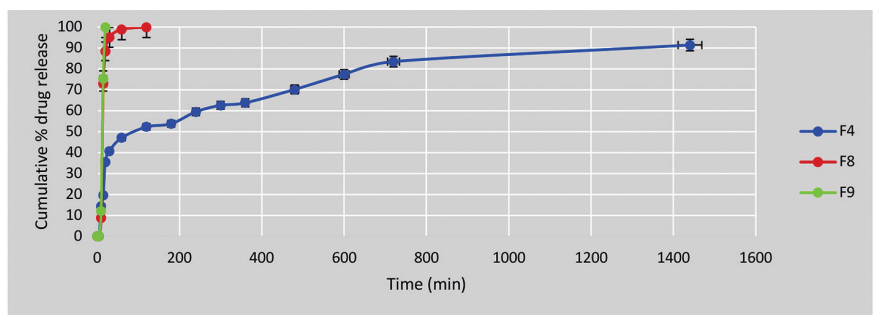

Figure 4. Dissolution profile of enalapril from floating microspheres containing different concentrations of enalapril (F4, F8, and F9), data given in mean $\pm \mathrm{SD}, \mathrm{n}=3$

SD: Standard deviation
$\mathrm{CaCl}_{2}$ concentration affected drug release (F4, F10, and $\left.\mathrm{F} 11\right)$ significantly ( $p<0.05)$, as shown in Figure 5. It was shown that the drug release decreased with an increase in the concentration of calcium chloride. This is attributed to the formation of a tight junction between the MM/GG residues of sodium alginate with calcium ion, which in turn decreases the swelling capacity of the microspheres. Therefore, enalapril cannot be readily released from the microspheres, as the surface roughness and porosity increase and the steric entanglements comprise a strong barrier; thus poor entry of dissolution medium into the polymer matrix may delay drug release. ${ }^{63}$

\section{Kinetic assessment of dissolution data}

The release pattern of enalapril in gastric fluid $0.1 \mathrm{~N} \mathrm{HCl}$, $\mathrm{pH}$ 1.2) from all formulations of floating microspheres ( $F 1$ to F11) followed the Higuchi matrix model as shown in Table 4. The effervescent floating systems obeyed the Higuchi model, indicating drug release via a diffusion mechanism. In addition, formulations F1, F6, and F7 were observed to have $n$ values of 0.43 or less, with the release mechanism following Fickian diffusion. ${ }^{27}$ Formulations F5, F8, F9, and F11 were observed to have a high $n$ value of $>0.84$; thus the mechanism of drug release is regarded as super case II transport. The value of the release rate exponent $(n)$ of the Korsmeyer-Peppas release model for F2, F3, F4, and F10 was $0.43<n<0.84$ for mass transport, which follows a non-Fickian model (anomalous transport). Therefore, it can be concluded that F4 was the optimum formula and the drug release was mainly following anomalous transport, which corresponds to a diffusion, erosion, and swelling mechanism or mixed-order kinetics. ${ }^{64}$

\section{Interaction study and identification of drug excipients}

\section{FT-IR}

FT-IR spectroscopy was carried out to establish the compatibility of enalapril with polymers after the preparation of microspheres. Individual FT-IR scanning of the pure drug powder (Figure 6A) and polymers (sodium alginate, iotacarrageenan) is shown in Figures $6 \mathrm{~B}$ and $6 \mathrm{C}$, respectively, in addition to enalapril microspheres (F4) in Figure 5D.

The FT-IR spectrum for pure enalapril was distinguished by the principal absorption bands at $1753 / \mathrm{cm}$ due to $\mathrm{C}=0$ stretching (ester), at $1649 / \mathrm{cm}$ due to $\mathrm{N}-\mathrm{H}$ bending, and at $1444 / \mathrm{cm}$ due to $\mathrm{C}-\mathrm{H}$ (alkanes) bending. ${ }^{65}$ The FT-IR spectrum of sodium alginate was characterized by absorption bands at 2933, 1610, 1421, and $1033 / \mathrm{cm}$ due to stretching of $-\mathrm{CH},-\mathrm{COOH},-\mathrm{CH}$,

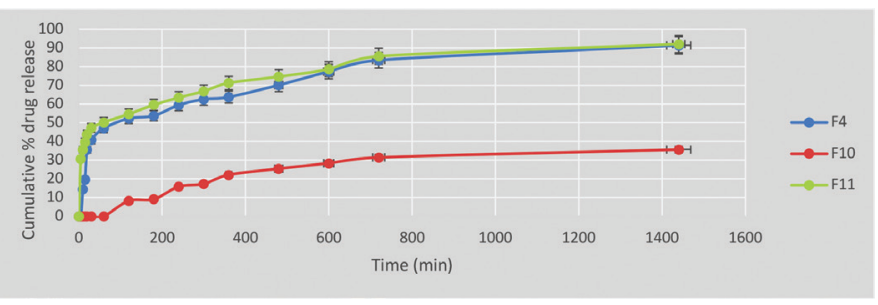

Figure 5. Dissolution profile of enalapril from floating microspheres containing different concentrations of $\mathrm{CaCl}$ ( $F 4, F 10$, and $\mathrm{F} 11$ ), data given in mean $\pm \mathrm{SD}, \mathrm{n}=3$

SD: Standard deviation 
and $-\mathrm{C}-\mathrm{O}-\mathrm{C}$, respectively. ${ }^{66}$ In addition, the $\mathrm{FT}-\mathrm{IR}$ spectrum of iota-carrageenan was observed with characteristic bands at $1228 / \mathrm{cm}$ for the ester sulfate group, $918 / \mathrm{cm}$ for 3,6 -anhydrogalactose, $846 / \mathrm{cm}$ for galactose-4-sulfate, and 771/ $\mathrm{cm}$ for 3,6-anhydrogalactose-2-sulfate. ${ }^{67}$

The IR spectra patterns for microspheres (F4) were compared with the IR spectrum of the pure drug for confirmation of the major functional groups. All the characterized bands of enalapril with polymers appeared and indicated no significant variation in the peaks, suggesting that the drug and excipients were compatible. Moreover, it shows that there was no interaction between pure enalapril powder and the polymers used. Subsequently, it can be decided that the drug is chemically

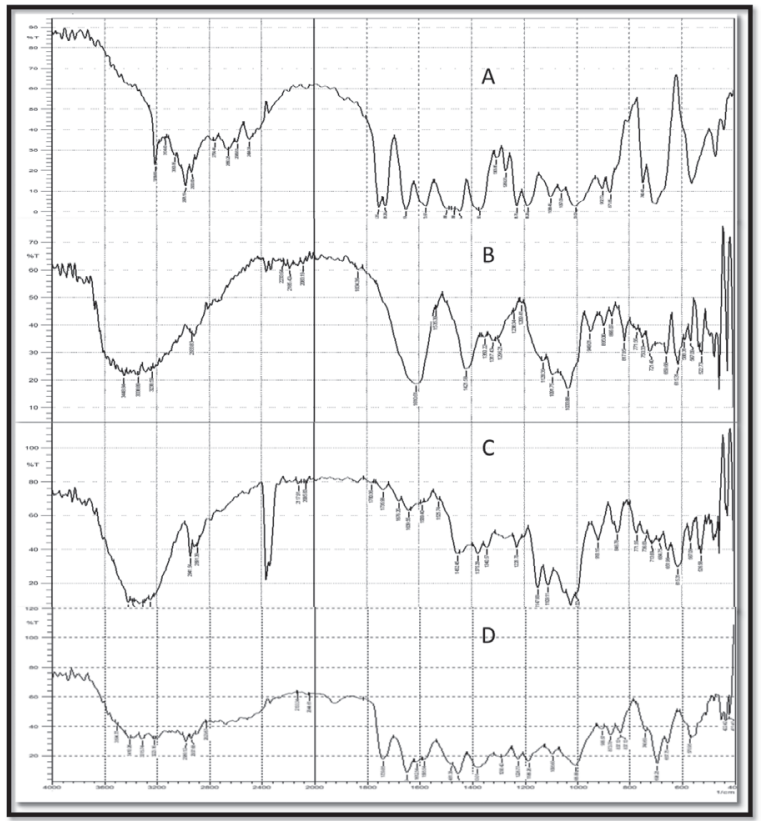

Figure 6. The FT-IR spectra for (A) pure enalapril; (B) sodium alginate; (C) iota-carrageenan; (D) enalapril microspheres (F4)

FT-IR: Fourier transform-infrared spectroscopy stable in the polymer matrix and can be released with ease from microspheres.

\section{Surface morphology}

The surface morphology of microspheres represented by the particle size and a characteristic shape was determined by SEM. The SEM images of microspheres taken at different magnifications are shown in Figure 7. It was noted in the SEM images that the microspheres were spherical, discrete, and freely flowing. In addition, the surfaces were slightly rough and drug crystals were also present on the surface of the microspheres. These drug crystals were responsible for the burst release of drug from the microspheres. ${ }^{68}$

\section{$P X R D$}

The X-ray diffraction of pure enalapril, sodium alginate, iotacarrageenan, and F4 is shown in Figure 8. It was observed

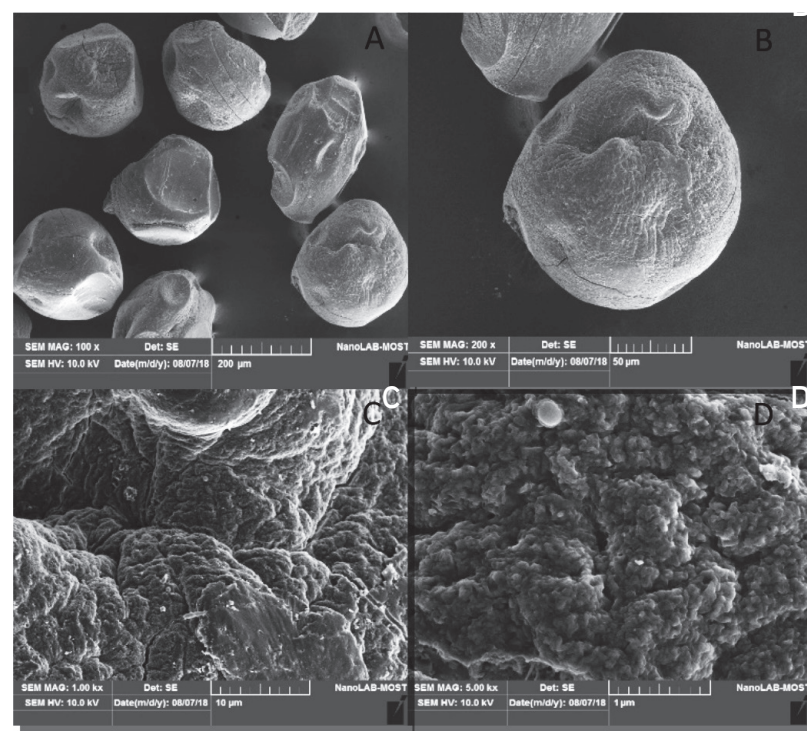

Figure 7. Scanning electron microscopy for $F 4$ represents different magnifications A) 100x; B) 200x; C) 1K; D) 5K

Table 4. Kinetic data models for the prepared enalapril microspheres

\begin{tabular}{llllllllll} 
Formulation & Zero-order & \multicolumn{3}{c}{ First-order } & \multicolumn{3}{c}{ Higuchi-order } & \multicolumn{3}{c}{ Korsmeyer-Peppas } \\
\cline { 2 - 9 } & $\mathrm{K}_{0}\left(\mathrm{mg} \mathrm{h}^{-1}\right)$ & $\mathrm{R}^{2}$ & $\mathrm{~K}_{1}\left(\mathrm{~h}^{-1}\right)$ & $\mathrm{R}^{2}$ & $\mathrm{~K}_{\mathrm{H}}\left(\mathrm{h}^{-1 / 2}\right)$ & $\mathrm{R}^{2}$ & $\mathrm{n}$ & $\mathrm{K}_{\mathrm{kp}}\left(\mathrm{h}^{-1 / 3}\right)$ & $\mathrm{R}^{2}$ \\
\hline F1 & 0.0203 & 0.6177 & -0.0003 & 0.7375 & 0.8844 & 0.8443 & 0.3509 & 1.0278 & 0.4676 \\
\hline F2 & 0.0359 & 0.5419 & -0.0003 & 0.7234 & 1.5826 & 0.7563 & 0.5372 & 0.4572 & 0.6573 \\
\hline F3 & 0.0392 & 0.5623 & -0.0003 & 0.671 & 1.7546 & 0.8089 & 0.6158 & 0.1383 & 0.7955 \\
\hline F4 & 0.0983 & 0.7108 & -0.0009 & 0.8214 & 2.7776 & 0.8462 & 0.5789 & 0.4298 & 0.6399 \\
\hline F5 & 0.0357 & 0.4806 & -0.0002 & 0.5361 & 1.6643 & 0.7502 & 0.8606 & -0.5975 \\
\hline F6 & 0.0545 & 0.6268 & -0.0007 & 0.7741 & 1.7369 & 0.7963 & 0.176 & 1.4368 & 0.7932 \\
\hline F8 & 0.072 & 0.9510 & -0.0008 & 0.985 & 1.72 & 0.9887 & 0.13 & 1.5117 & 0.9627 \\
\hline F9 & 1.6325 & 0.5322 & -0.057 & 0.803 & 42.927 & 0.7805 & 1.2111 & -0.0982 & 0.7582 \\
\hline F10 & 7.264 & 0.9373 & -0.0607 & 0.8185 & 44.375 & 0.8114 & 1.6255 & -0.3657 & 0.7534 \\
\hline F11 & 0.0302 & 0.7975 & -0.0002 & 0.8338 & 1.2281 & 0.9486 & 0.8423 & -0.9491 \\
\hline
\end{tabular}


that the pure enalapril powder exhibited highly intense, sharply distinctive, and narrow diffraction peaks at $2 \theta$ of $10.48,20.92$, 24.89, and 31.57, indicating that the drug was a highly stable crystalline. However, when the drug was incorporated into the polymer matrix, the principal peaks of the drug diffractogram were observed with lower intensity. This could be ascribed to the crystalline state of the drug in the microsphere. ${ }^{69}$

DSC

DSC studies were performed to investigate the physical state of the drug in the microspheres because this aspect could influence the in vitro and in vivo release of the drug from the systems. Figure 9 shows the DSC thermogram of pure enalapril powder, sodium alginate, iota-carrageenan, and F4

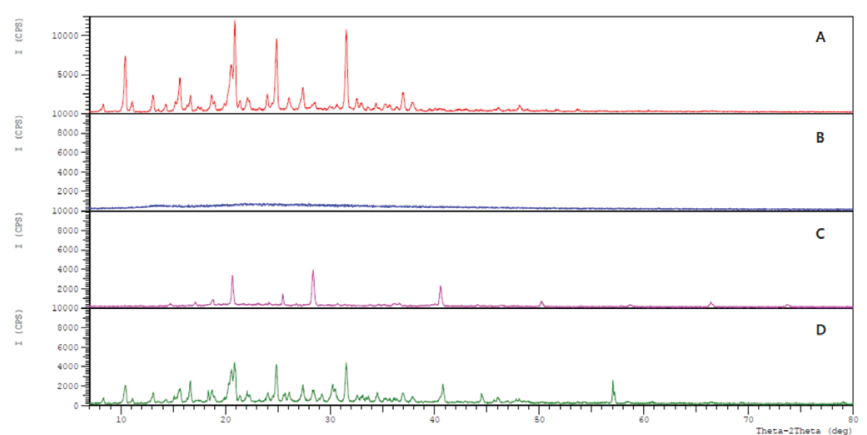

Figure 8. X-ray diffraction patterns of A) pure enalapril powder; B) sodium alginate; C) iota-carrageenan; D) F4

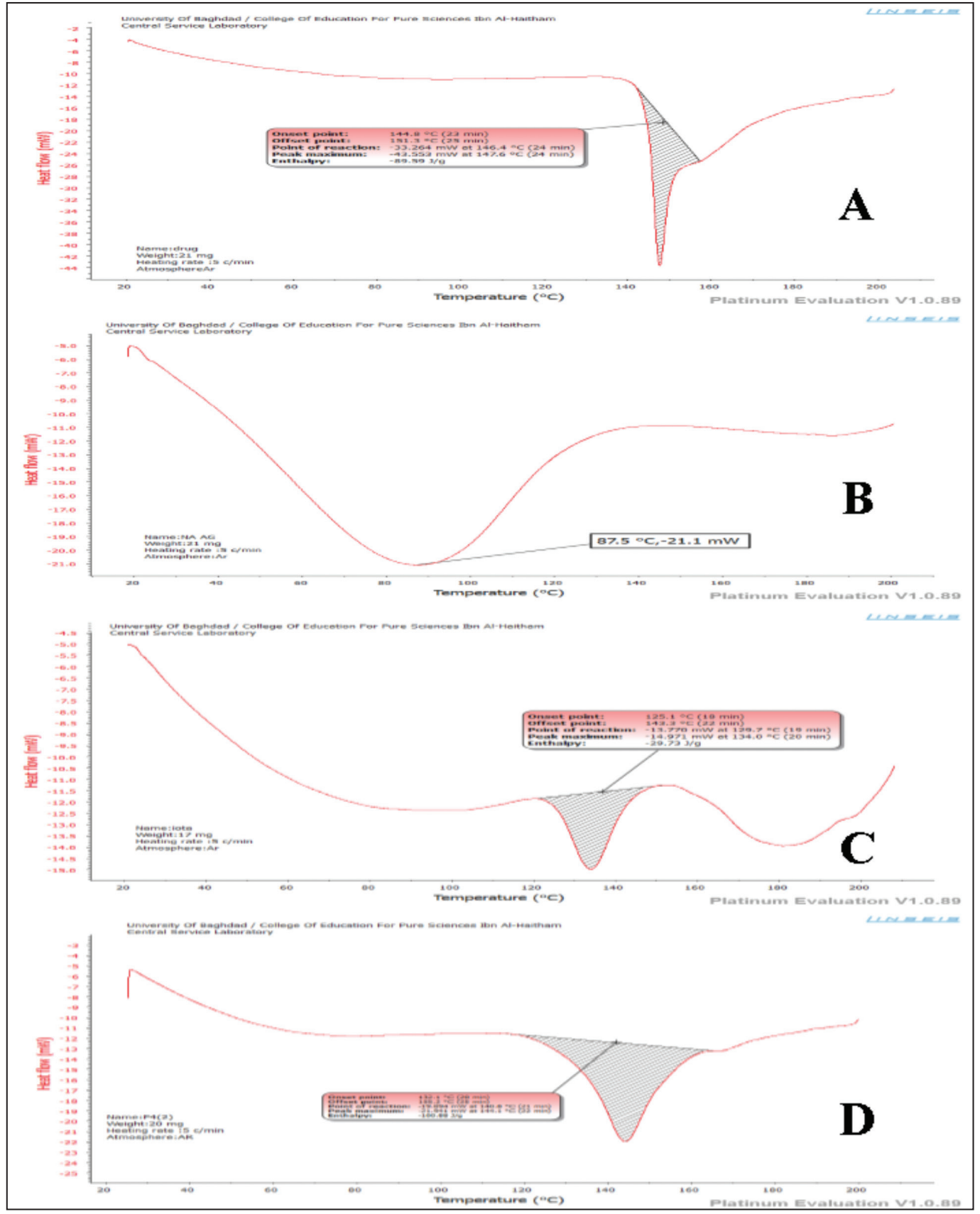

Figure 9. Differential scanning calorimetry patterns of A) pure enalapril powder; B) sodium alginate; C) iota-carrageenan; D) F4 
as microspheres. Pure powder of enalapril showed a sharp endothermic peak at $147.6^{\circ} \mathrm{C}$ corresponding to its melting point, while sodium alginate showed a broad endothermic peak at around $87^{\circ} \mathrm{C}$, which was mainly due to loss of water. The endothermic peak of the iota-carrageenan was observed at $134^{\circ} \mathrm{C}$; that has a narrower peak compared with sodium alginate, which may be attributed to the lower numbers of hydrophilic $\mathrm{OH}$ groups (anhydride bridge). The appearance of a broader peak in $\mathrm{F} 4$ with minimum shifting in position indicates the presence of the crystalline drug in the microsphere samples at least at particle surface level. Therefore, it could be concluded that F4 has shown the miscibility of the drug with the polymers while maintaining stable characteristic properties of enalapril loaded in the prepared microspheres. ${ }^{70-72}$

\section{CONCLUSION}

The present study established the prepared enalapril maleate microspheres through ionotropic gelation to provide better therapeutic efficacy, as a result of the continuous availability of the drug. In vitro release studies showed a significant decrease in drug release with an increment in sodium alginate concentration and calcium chloride concentration and higher concentrations of iota-carrageenan. At the same time, the effects of sodium bicarbonate and drug concentration increment on drug release were nonsignificant. FTIR spectra suggested that the drug and excipients were compatible. Surface morphology showed a spherical shape with rough surface microspheres. $X$-ray diffraction showed the crystalline state of the drug. The DSC studies displayed miscibility of the drug with the polymers. The overall result indicates promising pharmaceutical dosage form of enalapril maleate loaded floating microspheres.

\section{ACKNOWLEDGMENT}

The authors would like to thank Mustansiriyah University (www.uomustansiriyah.edu.iq), Baghdad, Iraq, for its support in the present work.

Conflict of Interest: No conflict of interest was declared by the authors.

\section{REFERENCES}

1. Anusha K, Krishna SA. Preparation and evaluation of mefenamic acid loaded microspheres using synthetic and natural polymers. Der Pharmacia Lettre. 2016;8:197-205.

2. Kamel R. Multiparticulate carriers for controlled oral drug delivery. Pharm Sci Tech. 2016;1:1-3.

3. Swapna N, Jithan A. Preparation, characterization and in vivo evaluation of parenteral sustained release microsphere formulation of zopiclone. $J$ Young Pharm. 2010;2:223-228.

4. Varde NK, Pack DW. Microspheres for controlled release drug delivery. Expert Opin Bio Ther. 2004;4:35-51.

5. Berkland C, King M, Cox A, Kim K, Pack DW. Precise control of PLG microsphere size provides enhanced control of drug release rate. $J$ Control Release. 2002;82:137-147.
6. Zhang $\mathrm{H}, \mathrm{Xu} \mathrm{J}$. Enhanced oral bioavailability of salmeterol by loaded PLGA microspheres: preparation, in vitro, and in vivo evaluation. Drug Deliv. 2014;23:248-253.

7. Freitas S, Merkle HP, Gander B. Microencapsulation by solvent extraction/evaporation: reviewing the state of the art of microsphere preparation process technology. J Control Release. 2005;102:313-332.

8. Mukund JY, Kantilal BR, Sudhakar RN. Floating microspheres: a review. Brazilian J Pharm Sci. 2012; 48:17-30.

9. Shashank C, Prabha K, Sunil S, Vipin Kumar A. Approaches to increase the gastric residence time: floating drug delivery systems - a review. Asian J Pharm Clin Res. 2013;6:1-9.

10. Chugh C, Nanda A. Gastroretentive drug delivery systems - a review. Int J Pharm Bio Sci. 2017;8:62-68.

11. Prakash S, Bhandari A, Mishra R, Sharma PK. Development and optimization of floating microspheres of gliclazide. Int J Pharm Sci Res. 2015;6:807-817.

12. Aly Kassem M, El Assal MIA, Al-Badrawy AA. Preparation and evaluation of certain hydrophilic drug-loaded microspheres. Int Res J Pharm. 2012;2:82-90.

13. Miladi K, Ibraheem D, Iqbal M, Sfar S, Fessi H, Elaissari A. Particles from preformed polymers as carriers for drug delivery. Exp Clin Sci Int J. 2014;13:28-57.

14. Patil P, Chavanke D, Wagh M. A review on ionotropic gelation method: novel approach for controlled gastroretentive gelispheres. Int J Pharm Pharm Sci. 2012;4:27-32.

15. Pahwa R, Neeta, Bhagwan S, Kumar V, Kohli K. Floating microspheres: an innovative approach for gastric retention. Der Pharmacia Lettre. 2010;2:461-475.

16. Nanjwade BK, Patel UD, Kadam VT, Idris NF, Srichan T. Formulation and evaluation of enalapril maleate biodegradable microspheres. J Pharm Sci Pharmacol. 2014;1:200-210.

17. Gadad AP, Naik SS, Dandagi PM, Bolmal UB. Formulation and evaluation of gastroretentive floating microspheres of lafutidine. Indian J Pharm Edu Res. 2016;50: S76-S81.

18. Sammour OA, El-Ghamry HA, El-Nahas HM, Barakat W. Development and characterization of controlled release ketoprofen microspheres. J App Pharm Sci. 2012;2:60-67.

19. Wasnik S, Parmar P, Singh D, Ram A. Preparation and characterization of floating drug delivery system of azithromycin. Acta Poloniae Pharmaceutica - Drug Res. 2012;69:515-522.

20. Bhardwaj P, Chaurasia D, Singh R, Swarup A. Development and characterization of novel site specific hollow floating microspheres bearing 5-Fu for stomach targeting. Sci World J. 2014:1-11.

21. Jagtap Y, Ranade A, Ranpise N, Bhujbal R. Effect of various polymers concentrations on physicochemical properties of floating microspheres. Indian J Pharm Sci. 2012;7:512-520.

22. Kusuma D, Krishnan KS, Sri S, Sree V. Formulation and evaluation of floating microspheres of acebutolol. Int J Pharm Sci Rev Res. 2017;46:31-36.

23. Dhanalakshmi G, Lakshmikanth M, Veena R. Design and characterization of itopride $\mathrm{HCl}$ floating microspheres. Int J Invent Pharm Sci. 2013;1:70-80.

24. Rane BR, Gujarathi NA, Patel JK. Preparation and in vitro characterization of floating microspheres of nateglinide. Int J Pharm Sci Res. 2012;3:4306-4313. 
25. Negi M, Shukla VK, Easwari TS. Preparation and evaluation of ofloxacin sustained released gastro retentive floating microspheres. UK J Pharm Biosci. 2014:2:19-24.

26. Pandya N, Pandya M, Bhaskar VH. Preparation and in vitro characterization of porous carrier-based glipizide floating microspheres for gastric delivery. J Young Pharm. 2011;3:97-104.

27. Jani P, Vadalia K, Bagdai H, Dedania R, Manseta P. Formulation and evaluation of controlled release floating microspheres of tolperisone hydrochloride. Asian J Pharm. 2012;6:190-197.

28. Maraie NK, Alhamdany AT, Mahdi ZH. Application of the new oroslippery technology in the preparation of enteric slippery coated tablet of naproxen. Int J Pharm Pharm Sci. 2017;9:198-204.

29. Sharma M, Kohli S, Dinda A. In-vitro and in-vivo evaluation of repaglinide loaded floating microspheres prepared from different viscosity grades of HPMC polymer. Saudi Pharm J. 2015;23:675-682.

30. Aute SM, Payghan SA, Mali SS, Patrekar PV. Development of floating microspheres of anti-ulcer drug as a gastroretentive drug delivery system. Der Pharmacia Lettre. 2015;7:364-377.

31. Aute SM, Kate VK, Payghan SA. Formulation of floating microspheres of nizatidine: investigation of effect of solvent evaporation and spray drying technique. Inventi Impact: NDDS. 2015;3:85-100.

32. Chouhan M, Chundawat AVS, Chauhan CS. Development and characterization of floating microspheres of esomeprazole magnesium trihydrate by solvent evaporation method. Int J Pharm Sci Res. 2017;8:686-697.

33. Gasperini L, Mano JF, Reis RL. Natural polymers for the microencapsulation of cells. J Royal Society Interface. 2018;15:1-19.

34. Leemsuthep A, Nayan NAM, Zakaria Z, Lan DNU. Effect of sodium bicarbonate in fabrication of carbon black-filled epoxy porous for conductive application. Macromol Symposia. 2017;371:44-49.

35. Vaidya A, Jain A, Khare P, Agrawal RK, Jain SK. Metronidazole loaded pectin microspheres for colon targeting. J Pharm Sci. 2009;98:42294236.

36. Patil SB, Sawant KK. Development, optimization and in vitro evaluation of alginate mucoadhesive microspheres of carvedilol for nasal delivery. J Microencapsulation. 2009;26:432-443.

37. Pravallika YV, Rajyalakshmi K. Formulation and evaluation of gastroretentive hydrochlorothiazide floating microspheres: statistical analysis. Pharma Tutor. 2011;4:28-36.

38. Yegappan R, Selvaprithiviraj V, Amirthalingam S, Jayakumar R. Carrageenan based hydrogels for drug delivery, tissue engineering and wound healing. Carbohydrate Polymers. 2018;198:385-400.

39. Venkateswarlu K, Preethi JK, Kiran BSS. Formulation development and in-vitro evaluation of floating tablets of ciprofloxacin $\mathrm{HCl}$. Asian $\mathrm{J}$ Pharm. 2016;10:271-278.

40. Garcia JG, Ghaly ES. Preliminary evaluation of glipizide spheres and compacts from spheres prepared by cross-linking technique. Puerto Rico Health Sci J. 2001;20:25-30.

41. Semalty A, Adhikari L, Pandey M. Development and evaluation of alginate microspheres of paracetamol: effect of different concentrations of crosslinking agent and coating. Int Res J Invent Pharm Sci. 2014;2:2832.

42. Vinodbhai PK, Gohel MC, Parikh RK, Bariyac S, Suthar RN. Sustained release floating microspheres of acyclovir: formulation, optimization, characterization and in vitro evaluation. Int J Drug Develop Res. 2011;3:242-251.

43. Lohani A, Singh G, Bhattacharya SS, Hegde RR, Verma A. Tailoredinterpenetrating polymer network beads of k-carrageenan and sodium carboxymethyl cellulose for controlled drug delivery. J Drug Del Sci Tech. 2016;31:53-64.

44. Farooq U, Khan S, Shahid Nawaz S, Ranjha NM, Haider MS, Khan MM, Nawaz A. Enhanced gastric retention and drug release via development of novel floating microspheres based on Eudragit E100 and polycaprolactone: synthesis and in vitro evaluation. Designed Monomers and Polymers. 2017;20:419-433.

45. Shadab Md, Ahuja A, Khar RK, Baboota S, Chuttani K, Mishra AK, Ali J. Gastroretentive drug delivery system of acyclovir-loaded alginate mucoadhesive microspheres: formulation and evaluation. Drug Deliv. 2011;18:255-264.

46. Sankalia MG, Mashru RC, Sankalia JM, Sutariya VB. Physicochemical characterization of papain entrapped in ionotropically cross-linked kappa-carrageenan gel beads for stability improvement using Doehlert shell design. J Pharm Sci. 2006;95:1994-2013.

47. Jassem NA, Rajab NA. Effect of effervescent agents on the formulation of famotidine loaded sodium alginate floating beads. Kerbala J Pharm Sci. 2012;4:166-176.

48. Sipahigil O, Dortunc B. Preparation and in vitro evaluation of verapamil $\mathrm{HCl}$ and ibuprofen containing carrageenan beads. Int J Pharm. 2001;228:119-128.

49. Patil NN, Patil KP, Pawar SP, Tadvi SA. Formulations and evaluations of metformin microspheres by ionotropic gelation technique. World $J$ Pharma Pharm Sci. 2017; 6:1473-1486.

50. Selvakumaran S, Muhamad II. Optimization of formulation of floating hydrogels containing gas forming agent using response surface methodology. Int J Pharm Pharm Sci. 2014;6:526-530.

51. Selvakumaran S, Muhamad II, Razak SIA. Evaluation of kappa carrageenan as potential carrier for floating drug delivery system: effect of pore forming agents. Carbohydrate Polymers. 2016;135:207214.

52. Maravajhala V, Dasari N, Sepuri A, Joginapalli S. Design and evaluation of niacin microspheres. Indian J Pharm Sci. 2009;71:663-669.

53. Nagpal M, Maheshwari DK, Rakha P, Dureja H, Goyal S, Dhingra G. Formulation development and evaluation of alginate microspheres of ibuprofen. J Young Pharm. 2012;4:13-16.

54. Ghareeb MM, Issa AA, Hussein AA. Preparation and characterization of cinnarizine floating oil entrapped calcium alginate beads. Int J Pharm Sci Res. 2012;3:501-508.

55. Alhamdany AT, Maraie NK, Msheimsh BR. Development and in vitro/ in vivo evaluation of floating in situ gelling oral liquid extended release formulation of furosemide. UK J Pharm Biosci. 2014;2:1-11.

56. Ozdemir O, Çelik MS, Nickolov ZS, Miller JD. Water structure and its influence on the flotation of carbonate and bicarbonate salts. J Colloid Interface Sci. 2017;314:545-551.

57. Dinarvand R, Moghadam SH, Mohammadyari-Fard L, Atyabi F. Preparation of biodegradable microspheres and matrix devices containing naltrexone. AAPS PharmSciTech. 2003;4:1-10.

58. Moganti M, Shivakumar HN. Formulation and evaluation of gastroretentive-floating multiparticulate system of lisinopril. Indian J Health Sci Biomed Res. 2017;10:50-56. 
59. Lemoine D, Wauters F, Bouchend S, Preat V. Preparation and characterization of alginate microspheres containing a model antigen. Int J Pharm. 1998;176:9-19.

60. Rajinikanth PS, Sankar C, Mishra B. Sodium alginate microspheres of metoprolol tartrate for intranasal systemic delivery: development and evaluation. Drug Deliv. 2003;10:21-28.

61. Varghese JS, Nisha C, Fathima NN. Gelatin-carrageenan hydrogels: role of pore size distribution on drug delivery process. Colloids and Surfaces B: Biointerfaces. 2014;133:346-351.

62. Benita S, Barkai A, Pathak YV. Effect of drug loading extent on the in-vitro release kinetic behaviour of nifedipine from polycrylate microspheres. J Control Release. 1990;12:213-222.

63. Manjanna KM, Pramod Kumar TM, Shivakumar B. Effect of manufacturing conditions on physico-chemical characteristics and drug release profiles of aceclofenac sodium microbeads. Drug Invent Today. 2009;1:98-107.

64. Ansary J, Chaurasiya AK, Bashirul Huq KM. Formulation and evaluation of metformin $\mathrm{HCl}$ floating microspheres. Asian $\mathrm{J}$ Med Bio Res. 2015;1:396-405

65. Kameswara RS, Yusuf MD, Saraswathi P, Rao CRR, Murali P, Vijayakumar V. Formulation and evaluation of orodispersible enalapril maleate tablets: a comparative study on natural super disintegrants and synthetic super disintegrants. Int J Adv Sci Res. 2015;1:313-321.
66. Wang K., He Z. Alginate-konjac glucomannan-chitosan beads as controlled release matrix. Int J Pharm. 2002;244:117-126.

67. Volery P, Besson R, Schaffer-Lequart C. Characterization of commercial carrageenans by Fourier transform infrared spectroscopy using singlereflection attenuated total reflection. J Agri Food Chem. 2004;52:74577463.

68. Chavan MS, Sarode S, Bhushankumar S, Vadnere GP. Formulation and evaluation of sustained release microspheres of acebutolol hydrochloride. World J Pharm Pharm Sci. 2014;3:636-646.

69. Sethi RK, Barik BB, Sahoo SK. Preparation and determination of drugpolymer interaction and in-vitro release of didanosine microspheres made of cellulose acetate phthalate or ethylcellulose polymers. Int J Drug Develop Res. 2013;5:341-353.

70. Jelvehgari M, Hassanzadeh D, Kiafar F, Loveymi BD, Amiri S. Preparation and determination of drug-polymer interaction and in-vitro release of mefenamic acid microspheres made of cellulose acetate phthalate and/ or ethylcellulose polymers. Iranian J Pharm Res. 2011;10:457-467.

71. Rao KM, Rao KSVK, Sudhakar P, Rao KC, Subha MCS. Synthesis and characterization of biodegradable poly (vinyl caprolactam) grafted on to sodium alginate and its microgels for controlled release studies of an anticancer drug. J Applied Pharm Sci. 2013;3:61-69.

72. Mohamadnia Z, Zohuriaan-Mehr MJ, Kabiri K, Jamshidi A, Mobedi H. lonically cross-linked carrageenan-alginate hydrogel beads. J Biomater Sci Polym Ed. 2008;19:47-59. 